\title{
Reproduction of volcanic rituals in appealing for the right to live in disaster-prone zones on Mount Merapi
}

\section{Reproduksi Ritual Vulkanik untuk Memohon Hak Hidup di Kawasan Rawan Bencana Gunung Merapi}

\author{
Bambang Hudayana \\ ${ }^{1}$ Department of Anthropology, Faculty of Cultural Sciences, Universitas Gadjah Mada \\ ${ }^{2}$ Head of the Center for Rural and Development Studies, Universitas Gadjah Mada \\ Address: ${ }^{1}$ Sosiohumaniora Street No. 3, Bulaksumur, Depok, Sleman Yogyakarta, 55281 \\ ${ }^{2}$ Bulaksumur, Sleman, Yogyakarta, Indonesia, 55281 \\ E-mail: bambang.hudayana@ugm.ac.id
}

Article History: Received 24 September 2020; Accepted 8 April 2021; Published Online 20 April 2021

\begin{abstract}
In response to the Mount Merapi eruption in 2010, the government had conducted several disaster risk reduction programs. However, the programs had ironically threatened hamlets as communities regarding their rights to practice their local knowledge and live in their home ground. This study employed a qualitative method involving five hamlets from December 2019 until February 2020. The data were collected by employing participatory observation and depth interviews, involving the ritual organizers, participants, citizens, guests, and other audience. Spirited by ritual theory as political action, this research showed that the hamlets formulated volcanic ritual reproductions into three forms which were the delegitimation of the disaster risk reduction programs, the reinforcement of Kejawen identity, and the showing off the safety and prosperity. Those reproductions were recognized by the emergence of new ritual processions in the forms of parades, pilgrimages, offerings, and enhancements of ritual formalization and celebrations. Those reproductions positively impacted the literacy and recognition from both the government and general society that those hamlets have been living a safe and prosperous life in Merapi, even though they are located in disaster-prone areas.
\end{abstract}

Keywords: delegitimation; Kejawen identity; Merapi eruption; recognition; volcanic ritual reproduction

\section{Abstrak}

Dalam merespons erupsi Merapi tahun 2010, pemerintah telah melakukan beberapa program pengurangan risiko bencana erupsi Gunung Merapi 2010. Namun demikian, program tersebut justru mengancam dusun sebagai komunitas terkait haknya untuk mempraktikkan pengetahuan lokal dan tinggal di kampungnya. Artikel ini bertujuan untuk mengungkap bentuk reproduksi ritual vulkanik untuk memohon hak hidup di kawasan rawan bencana Gunung Merapi. Studi ini menggunakan metode kualitatif di lima dusun pada Desember 2019 sampai dengan Februari 2020. Data dikumpulkan dengan cara melakukan observasi partisipan dan wawancara mendalam dengan melibatkan penyelenggara, peserta upacara, warga, penonton, dan tamu dalam upacara. Dengan berdasar pada teori ritual sebagai tindakan politik, penelitian ini menunjukkan bahwa dusun-dusun melakukan reproduksi ritual vulkanik ke dalam tiga bentuk, yakni delegitimasi program pengurangan risiko bencana, penguatan identitas Kejawen, dan bentuk pamer keselamatan dan kesejahteraan. Reproduksi tersebut tampak pada munculnya prosesi baru dalam ritual misalnya pawai, ziarah, sesaji, dan peningkatan formalitas ritual dan perayaan. Reproduksi tersebut pada akhirnya berhasil meningkatkan literasi dan rekognisi pemerintah dan masyarakat luas bahwa dusun-dusun itu hidup aman dan sejahtera di Merapi, sekalipun terletak di kawasan rawan bencana.

Kata kunci: deligitimasi; identitas Kajawen; erupsi Merapi; rekognisi; reproduksi ritual vulkanik

\section{Introduction}

There are dozens of active volcanic mountains in Java, and for local communities, the volcanoes are part of their ecological adaptation. Volcanoes provide fertile soil and springs that flow from the upper slopes down to the lowlands supporting rice farming. However, volcanos often cause disasters, which has compelled the Javanese to develop ecological adaptations to survive, such as developing traditional mitigation and belief system (Donovan \& Suharyanto 2011, Dove 2008, Dove \& Hudayana 2008). 
The Mataram Kingdom rulers believed in the supernatural power of volcanoes as the Javanese have continued to do until now (Purnomo \& Hariyanto 2014, Donovan \& Suharyanto 2011, Triyoga 2011, Dove 2008, Dove \& Hudayana 2008, Ahimsa-Putra 2000). The Sultan preserves this belief through the annual Sekaten festival, where the Sultan gives the people a gunungan (miniature mountain of blessed food) as a symbol that the Sultan's power, who is close to the mountain rulers, generates prosperity. The Sultan also performs the annual offering (labuhan) ritual, which is believed to be able to keep the threat of mount eruptions (Permana et al. 2017, Triyoga 2011, Dove 2008). Local communities also have their own rituals used for disaster mitigation (Permana et al. 2017, Gunawan 2015, Purnomo \& Hariyanto 2014, Triyogo 2011, Dove \& Hudayana 2008, Ahimsa-Putra 2000).

In this paper, these local rituals are referred to as volcanic rituals as hamlet communities serve to develop adaptations in volcanic disaster areas. The local ritual is not labuhan of Merapi as an offering ritual conducted by Sultan which is categorized as a community ritual in another article (Permana et al. 2017). The term ritual describes an activity of religious groups used for worshiping, paying respect, or giving offerings to sacred objects, while a ceremony describes an activity of religious or non-religious groups performed for rites, commemorations, or giving thanks that may be directly or indirectly related to ritual activities.

This article illustrated that during the last 10 years (2010-2019), the hamlets in the disaster-prone area (KRB III) have created reproductions of volcanic rituals. The KRB III is located 3-7 kilometers from the peak of Merapi. Using political ritual theory, this article revealed that the reproduction of volcanic rituals aims to delegitimize the government's disaster risk reduction programs. These programs are indeed disparaging of the volcanic rituals and have restricted the Merapi people live in the KRB III. Delegitimation negates the word "legitimacy". In theory, one of the reasons for the emergence of political legitimacy is because a government's presence in implementing programs that share similar views to those who provide legitimacy (Heywood 2013).

Political rituals are cultural actions that depict an attitude of rejection towards government programs. This rejection does not have to be understood as an act of delegitimation, but rather as an effort to develop literacy and gain recognition among the wider community and the government on the right to live in the KRB III. It is hoped that this can lead to appreciation from government and society for volcanic rituals as a strength in responding to disaster, and understanding that these communities can prosper and live safely on Merapi.

The theory associating ritual as a political action emerged in the Neo-Durkheim school of thought (Marshall 2002, Lukes 1975). Neo-Durkheim explains that initially, a ritual is derived from a community's need to build social integration (Marshall 2002, Luke 1975). In this ritual process, the political interest remains limited to efforts to build social integration. Individuals develop a collective awareness as part of a community through the ritual process, and this awareness creates a unified collective will as they are bonded by belief and devotion to the sacred objects that are worshipped.

Neo-Durkheim views the reproduction of community rituals as political rituals because the purpose of these rituals does not only serve to produce social integration but also to influence power relations (Marshall 2002, Lukes 1975). The reproduction of rituals is political in nature as it serves to resolve collective issues. When facing a collective problem, people usually take an action to resolve it. NeoDurkheim also defines political rituals as strengthening, re-creating, and organizing collective power in dealing with problems that must be resolved through ritual (Lukes 1975). In performing a political ritual, they become united to be able to focus on the problem and find concrete solutions (Sherly \& Curtin 2017).

Several studies have provided examples of viewing rituals as political actions. Geertz (1981) demonstrated that funeral rituals in Java are politicized as a means of strengthening the identity of the traditional Muslim (santri) group. The santri claims to have the authority to regulate rituals in an Islamic manner 
and deemed burials using Islamic rituals improper for their opposite group. Lapeña and Acabado (2017) also revealed that the Ifago community rituals can be used as part of their resistance strategy against the Spanish rulers. Reinhart (2015) illustrated that in the past, pottery craftsmen in China increased their social status by imitating the rituals performed by the rulers. Meanwhile, Heilbronner (2015) described the emergence of young Israelis who demonstrated resistance to the culture and religion of their nation by practicing secular rituals.

The four experts agree with the idea of rituals as political actions. They all emphasize that rituals are used by the participants to build collective solidarity based on a common identity, which creates collective awareness to differentiate a group from others. The rituals are also utilized to contest other groups that are considered threatening. Geertz (1981) viewed rituals as a show of power to claim that a group of participants is the ones who are capable to carry out religious rituals. Apeña and Acabado (2017) stated that people possessing lower positions in power relations, build resistance by using rituals as a means of political mobilization. Reinhart (2015) placed rituals as a tool to build self-identity in a group to get recognized as part of a powerful group. Finally, Heilbronner (2015) considered rituals as both form and tool of resistance for youths possessing a liberal and secular subculture against religious and conservative elders.

\section{Research Methods}

This research involved hamlets as a unit of analysis since a hamlet is a community and it is an original territorial organization in Java. The hamlet also becomes a self-governing community, which includes their ritual and ceremonial affairs. There are 21 hamlets in the KRB III and five of them were selected for a case study on ritual reproduction. This study did not compare the forms of rituals between hamlets but rather described the similarity and diversity of the patterns performed by the hamlets in adapting to the environment and various reproductions of volcanic rituals based on data from the five hamlets.

The field research was conducted mainly from December 2019 to February 2020. The qualitative data collection was conducted through in-depth interviews with informants that consisted of five hamlet heads, seven ritual and ceremonial committees, twelve ritual participants, five local government staff, and several audiences. The researcher also held some participant observations towards the hamlets' cleansing rituals and attended several ceremonies as a guest. All primary data were supplemented with data on the disaster management programs done by National Agency for Disaster Management (BNPB).

The qualitative data mainly consisted of the informants' experiences in rolling over the volcanic rituals, and the reasons for using rituals for political actions, i.e. delegitimating the government's programs, strengthening up the Kejawen identity, and showing off the safe and prosperous life in Merapi. These qualitative data were supported by observation results which were then analyzed by employing the ethnographic method. This method describes, explains, and interprets the qualitative data gained to either generate or explore a relevant theory (Brewer 2000). This research investigated how the community describes the relevance of reproduction of volcanic rituals in dealing with political problems in adapting to disaster-prone areas. The most relevant analysis and theoretical references employed in this research were those stated by Geertz (1981) which see a ritual as a tool to construct identity, run political contestation, and build up political power to control the opposite political side.

\section{Results and Discussion}

\section{Five hamlet communities in Merapi}

The five hamlets located in the Merapi disaster-prone area (KRB III) selected as the research objects belong to different villages, sub-districts, and districts administratively. These hamlets were Balerante in Kemalang Sub-district, Klaten District (East zone); Turgo in Pakem Sub-district, Sleman District (South zone); Kaliuranglor in Srumbung Sub-district and Babatan in Talun Sub-district, Magelang District (West zone); and Stabelan in Tlogolele Sub-district, Boyolali District (North zone). 
The five hamlets have existed in KRB III much longer before the $19^{\text {th }}$ C. Each hamlet has commonly 250-500 people from 85-170 families. The household is generally small-scaled farmers and breeders. The land owned is only around 0.5 hectares and the number of cattle is around 2-3 heads per household. Their main occupations are dryland agriculture and cattle farms. They have varied commodities including corn (in Balerante), perennials (in Turgo), Salak fruit (in Kaliuranglor), and vegetables (in Stabelan and Babatan). Although small-scale farmers, they live in prosperity, in the sense that they are able to meet basic needs for food, shelter, and clothing. In fact, they can improve their quality of life as proven by the house construction from concrete walls and have motorcycles.

Following other hamlets in rural Java, hamlets in Merapi belong to self-governing communities. Generally, various hamlet matters have been decentralized at the neighborhood association level, but hamlets tend to manage the well-being of their people by relying on the strength of their social capital. A hamlet is apparently led by a hamlet head, who is directly elected by the residents. Commonly, the hamlet head is a figure possessing social trust due to their ability to act as a facilitator for community development. Meanwhile, the hamlet people are accustomed to utilizing social solidarity and mainly social capital. Therefore, they are able to build infrastructures such as access roads and clean water. By utilizing social capital, they also reinforce their resilience regarding the threat of natural disasters (Hudayana 2017). They also conduct any social exchanges to preserve the culture of reciprocal cooperation among its members.

\section{Volcanic ritual as an adaptation system for the Merapi hamlet communities}

Shadowed by the threat of Merapi eruptions that often occurred throughout the $20^{\text {th }}$ and early $21^{\text {st }}$ centuries, the five hamlets took the initiative to build an ecological adaptation system. This system is expected to reduce vulnerability to the catastrophic dangers of Merapi. They also strengthen their local knowledge in mitigating the eruption and their social capital to organize evacuations, reconstructions, and post-disaster recovery.

Before the enactment of Law No. 24 of 2007 concerning Disaster Management, which mandated the government to implement mitigation and evacuation programs, the Merapi people conducted rituals to encounter the threats of disaster. Each hamlet has a ritual leader, so-called modin. In addition, there are also other 1-3 spiritual figures as the vice modin when the primary modin is absent. The name of the ritual is slametan. A slametan is a shared ritual activity with many community members, where they usually sit together and chant prayers or mantras for blessings of protection, safety, virtue, or forgiveness from God, ancestors, holy spirits, spiritual beings, or supernatural powers (Boogert 2017, Wessing 2006, Woodward 1998, Geertz 1981). As in Java in general, the slametan on Merapi is a community ritual involving the whole family. A husband participates in the ritual, while his wife provides the food and offerings.

People who attend the slametan ritual are also called kenduri. In addition to praying together, the kenduri eat certain food together, consisting of a whole cooked chicken (ingkung) with numerous side dishes and rice shaped like a miniature mountain (tumpeng). The kenduri then pray for the ingkung which is then eaten by the ritual participants and their family members at home. The blessing is believed to come from eating the ingkung and the tumpeng (Nazaruddin 2013). A tumpeng is often called sego gunung (mountain of rice) and has become a symbol for blessings from the rulers of Merapi's invisible realm.

There are four types of volcanic rituals, including disaster mitigation and reconstruction rituals (merti bumi), Javanese New Year rituals, and hamlet cleaning rituals (Purnomo \& Hariyanto 2014). Mitigation rituals can increase resilience in the face of disaster (Pardo et al. 2015). Javanese New Year and hamlet cleansing rituals can be included as volcanic rituals as they incorporate sacred objects related to the theme of living safely in the Merapi. 
There are sacred objects under God that are worshipped or revered in volcanic rituals. They include the grandfather (Eyang) of Merapi as the central figure who heads the magical palace of Merapi; the danyang, the palace assistants who control the hamlets, villages, rivers, and sacred places; and the ancestors of hamlet founders (Wessing 2006). In every volcanic ritual, after offering prayers asking for salvation and blessings from God, the ritual leader will ask for the help of sacred objects. In Balerante and Kaliuranglor, these sacred objects include Eyang and the danyang. In Turgo, they are Eyang and Jumadil Kobro who have former living places on Mount Turgo. In Babatan, they are Eyang of Merapi, the cleric Petruk, and ancestors, and in Stabelan, they are Eyang and Sunan Bagor.

These sacred objects are the central focus in volcanic rituals based on the belief that in terms of the physical world, Merapi is only a landscape (in the human world), whereas, in terms of the supernatural world, Merapi is a landscape of living spirits with a king who is called the Eyang of Merapi and his followers (Triyoga 2011, Purnomo \& Hariyanto 2014). Eyang and his assistant spirits control eruption and fertility. Mitigation rituals are performed when Merapi changes from normal conditions to becoming increasingly active until the mountain violently erupts, which forces residents to evacuate.

The mitigation ritual process begins when the eruptions increase over a week. When it occurs, usually one to three people in each hamlet who are spiritually sensitive start to feel that they are getting symbolic messages (wisik) from sacred objects. The messages may come in the form of a dream or are whispered directly into the ears of those who are receptive. Wisik may also come from someone who has a sixth sense or is highly intuitive. After receiving the messages, residents under the leadership of the hamlet head or the head of religious affairs then hold a kenduri ritual.

The mitigation ritual is presented by local leaders in the five hamlets during a procession of giving gifts from humans to Eyang of Merapi. An eruption of the lava is believed to be a sign that Eyang and the spirits are having a wedding ceremony. Sometimes, in the middle of an eruption, the sounds of a gamelan are heard as evidence that the wedding ceremony is taking place. A Kenduri ritual offering food and beverages to Eyang as a gift is similar to giving a wedding gift at a wedding party.

The people in Stabelan also believe that they will be protected by an ancestor named Sunan Bagor. He is respected by Eyang of Merapi. A long time ago, he was an ascetic who chose to settle in Stabelan. When Merapi was erupting, he would usually pass on messages to the hamlet residents to be alert. The residents would then inform the head of the hamlet about the messages, which would be interpreted that Eyang of Merapi was holding a celebration. Therefore, they needed to arrange an offering. In an emergency, he can also ask his people to evacuate by sending a message through a dream and asking for Awas brand cigarette.

Second, Merapi people also have rituals for disaster reconstruction. After an eruption of Merapi subsides, the people usually immediately return to their hamlets. They then hold the hamlet cleansing (merti dusun) ritual. This ritual is conducted to restore the Earth to normal, which can be utilized as a place to live and grow crops. Through this ritual, they usually hold meetings to prepare for the activities where everyone assists to work in cooperation in constructing houses and public facilities. Through this ritual and the robust cooperation, residents strengthen community solidarity, which in turn increases their resilience during recovery periods.

The rituals of the Merapi people are similar to those of other communities in many places (Holmgaard 2019; Gianisa \& Le De 2018; Kyoo-Man 2015). These rituals positively influence their views and actions in responding to disaster and contribute to the recovery process (Kyoo-Man 2015), their success in managing disaster reconstruction (Gianisa \& Le De 2018), and their social cohesion to overcoming fear and uncertainty in communities regarding the disaster threats (Sherry \& Curtis 2017).

Third, the Merapi hamlets also perform a nightly ritual, Satu Suro, which is the Javanese New Year ceremony that has adopted the Islamic calendar. Many Javanese participate in this ritual, which is 
performed in the early evening and continues through the night with a tirakatan ritual, including chanting prayers, meditation, and observing oneself for a safe and prosperous life in the next year.

Fourth, like Javanese, the Merapi people conducted hamlet cleansing rituals annually. These rituals aim to serve their need to offer prayers and hopes for well-being and to live safely on the volcano. The sacred objects that are worshipped in various hamlet cleansing rituals are the same as those in the mitigation and new year rituals. The ritual is also followed by ceremonies in which all hamlets always performed shadow puppets (wayang kulit). The ceremony also includes eating together, usually while the shadow puppet show is being performed.

\section{Disaster risk and threat reduction programs for the five hamlet communities}

Even though the people in the five hamlets have been able to live safely and prosperously, they are in fact, are always shadowed by worries about threats related to their future. It is ironically caused by the emergence of government programs related to disaster risk reduction in Merapi. The government has reasons to execute the disaster risk reduction program consisting of mitigation, reconstruction; relocation; and the conversion of forest zones into the Mount Merapi National Park (TNGM). The reasons to proceed with the program are as follows.

First, Merapi, which is located in the Provinces of Special Region of Yogyakarta (DIY) and Central Java, is an active volcano and eruptions have often claimed victims. Merapi has had more than 80 major eruptions since 1672 up until 1996, with intervals of roughly 1-18 years or on average of every 4 years (Bronto \& Hartono 1996). In 2006, Merapi had quite a large eruption that claimed six lives and damaged the Kaliadem tourist area. Subsequently, significantly large eruptions occurred in October-November in 2010 that claimed 386 lives, consisting of 277 victims in DIY and 109 victims in Central Java. 15,366 people were displaced, 12,839 from DIY and 2,527 from Central Java (BNPB \& BAPPENAS 2011). During 2011-2019, Merapi erupted four times but all with low eruption rates, including in 2016, 2017, 2018, and 2019.

Second, the transmigration program as a strategy to save eruption victims was not popular and was mostly rejected. Many residents who took part in the transmigration program to Sumatra ended up returning to their home place as they considered the land on Merapi to be more fertile. In response, the government then offered a relocation program, moving residents from the KRB III to KRB II. The relocation program was ever been done for the Turgo Hamlet residents who were affected by the 1994 Merapi eruption. Following the 2010 Merapi eruption, the government reintroduced the relocation program from 2011-2015. The target population was approximately 25,000 residents, although only about 2,500 of them relocated.

Third, in encouraging the Merapi summit area not to be used for housing or livelihoods, the forest area was designated to become TNGM. Although this policy was established in 2004, the program did not eventuate at the time due to government budget constraints. The government only had a budget for the development of TNGM after the Merapi eruption in 2010. The TNGM target area, which is located at an altitude of approximately 2,500 meters above sea level covers an area of 6,410 hectares consist of 1,283.99 hectares in DIY, and 5,156.01 hectares in Central Java (Kuswijayanti et al 2007).

The TNGM was spontaneously rejected by all of the communities. The TNGM would have reduced their access to grass for livestock, sand, and settlements. Many cattle breeders depend on grass for a feed from the upper slopes. Distrust increased even further when the government granted sand mining licenses to private companies (Kuswijayanti et al 2007). The five hamlets hoped that the sand produced from the 2010 eruption could be used to fund their reconstruction costs of the disaster. There were approximately 130 million cubic meters of sand produced and scattered throughout the rivers as a result of the eruption (Aisyah \& Purnamawati 2012). 
Fourth, under Law No. 24 of 2007 concerning Disaster Management, the government developed three programs on mitigation, evacuation, and reconstruction in Merapi. These programs, however, clashed with the local knowledge system and threatened the people's right to live in KRB III. As an effect, the five hamlets distrust the government programs and prompted them to reproduce volcanic rituals as a political action to build up the literacy and recognition for the government that the hamlets are capable to live a safe and prosperous life in Merapi.

\section{The reproduction of volcanic rituals as a form of delegitimation of the disaster risk reduction programs}

For those living in KRB III, the threat of life appears when they are deemed by the government to be unable to survive because they only rely on local knowledge, beliefs, and rituals to mitigate disasters. This is because the government invited them to join the relocation program. The government also tends to discredit the people's local knowledge, beliefs, and rituals. As a result, they are challenged to prove that the reproduction of volcanic rituals can be used to show that they can prevent disasters and live safely even in disaster-prone areas. Therefore, this ritual reproduction is intended to delegitimize the government's disaster mitigation and reconstruction programs.

Prior to 2010, the government and public were considered illiterate in terms of volcanic rituals and beliefs, and the hamlets were not interested in brandishing their practices. However, with the 2010 eruption disaster, the hamlets felt compelled to showcase their rituals precisely so that the public, the Merapi eruption task force, and disaster volunteers, would gain some insight and be able to provide recognition.

Each hamlet invited guests such as the volunteers and task forces to attend their mitigation rituals. They advised that the mitigation rituals had to be heeded first before the task force and volunteers asked them to evacuate. The importance of the mitigation rituals provides cultural literacy that the Merapi people have a way to save themselves by carrying out rituals rather than merely carrying out evacuations.

In Stabelan, the reluctance of the task forces to understand the concept of mitigation rituals was still evident. A week before a large eruption on October 24 in 2010, the task forces were forcing residents to immediately evacuate. The evacuees were staying in evacuation barracks, but two days later they returned to their hamlet to organize a Sego Gunung offering. This occurred as some of them had received a mystical message from Sunan Bagor that they had to give offerings to Eyang of Merapi, who was holding a celebration, in other words causing Merapi to erupt on a large scale. Conducting this offering was a show of strength to the public that the ritual would save them, not the evacuation mobilization conducted by the government.

Another reason underlying the hamlet residents reproduced the volcanic rituals after the 2010 eruption was to increase cultural literacy among the officials in disaster awareness based on local knowledge. During 2011-2014, some officials, journalists, and researchers visited the hamlets to observe the response of residents regarding the government programs. In fact, the Merapi people reiterated the validity of their beliefs and traditions in the presence of these visitors. The head of Babatan Hamlet, for example, showcased the Kyai Petruk myth to the journalist. He told the journalist that the residents were wellloved by Petruk because they were diligent in giving offerings to Eyang on Merapi and proof of this love was that when there is an eruption, the people do not need to evacuate. In myth, it is said that in ancient times, Petruk was a powerful human who lived in the real world on Merapi. When he entered adulthood, he moved to Eyang's kingdom on Merapi and as such turned into a spirit. He became a royal official of the kingdom with the task of protecting the people from Merapi eruptions. Petruk usually reminds residents to be aware that Merapi is about to erupt by inviting them to hold rituals with offerings to Eyang of Merapi. 
By sharing and discussing knowledge on their beliefs, rituals, and myths, the hamlets were in fact, able to oppose the hegemony of modern mitigation that undermine traditional knowledge. Reproductions of the myths of Petruk, Bagor, and Jumadil Kobro became popular, and in disaster situations, these myths were deliberated with mass media, regional officials, and Kejawen practitioners. This led to the recognition that the local beliefs of the Merapi people regarding eruptions comprised local wisdom that is valuable in strengthening responsiveness in facing the threat of eruptions.

The five hamlets also increased the public's cultural literacy on disaster reconstruction rituals after the 2010 eruption. It was preceded by the government's decision to extend the 2010 Merapi eruption emergency response for another two months until March 2011. In February 2011, residents from the five hamlets returned to their house to end the emergency response by first performing a ritual. The purpose of this ritual was to challenge the government's view that Merapi was not yet safe. They believed that Merapi would not erupt again and they could conduct economic recovery sooner. In commencing the reconstruction activities, they performed the restoring the earth ritual with the intention that they could succeed and be safe without hindrance. Turgo and ten neighboring hamlets held shadow puppet shows as a series of reconstruction rituals, which received widespread public attention. Many people from neighboring hamlets came to watch the performances. Kejawen activists also watched to provide support for the rituals as a means for them to receive blessings from sacred objects for disaster recovery. In the view of Kejawen adherents, the performance had a religious magical element while it also preserved the beliefs and identity of Kejawen. This cultural performance depicted the discourse contestation between the Merapi people and the government about Merapi areas' safety and properness to live.

The five hamlets in Merapi did not evacuate after the 2010 eruption and did not partake in a reconstruction program either. The small Merapi eruptions, such as those that occurred once or twice in 2016, 2017, 2018 , and 2019, were routine eruption activities that do not endanger hamlet residents. As such, although the hamlets remain alert, they have not stopped raising awareness on their volcanic rituals and beliefs as the basis for gaining recognition.

After the 2010 Merapi eruption, the delegitimacy against the government programs emerged in five hamlets by performing greater rituals in order to strengthen up the cultural literacy and local knowledge on disaster reduction. In Balerante and Kaliuranglor, local knowledge was imparted through displaying sacred stones to visitors as the locations for giving offerings to Eyang of Merapi. While in Turgo, the residents built a parking lot and provided pilgrimage services to the Jumadil Kobro's sacred sites, and the Babatan residents developed an inventory of sacred places and built a Sunan Bagor's tombstone site. Dozens of people including officials, journalists, and NGO activists have made pilgrimages to these sacred sites in Merapi. These efforts imparting knowledge and insight have succeeded in gaining the public's recognition of local knowledge on disaster reductions.

The delegitimation by contesting volcanic rituals against the government's programs has resulted in increased recognition that hamlets have local wisdom regarding disaster management. The government's attitude was clearly evident with the BNPB initiative to hold a workshop on 27 August in 2020 on collecting local knowledge for Merapi disaster management in Yogyakarta. This BNPB initiative was similar in concept to what happened in Maori communities in trying to combine a mitigation system that's based on local wisdom with a modern mitigation system (Pardo et al. 2015).

This study found the reasons behind the reproduction of volcanic rituals related to political aspects. First, the ritual as an adaptation tool to disasters turns into political tools to build collective awareness to reduce government hegemony in mitigation and reconstruction programs. Second, the rituals are used to strengthen up the identity as part of the Javanese dominant group, the so-called Kejawen. Third, the rituals function as a show of force of the Merapi people that they can live a safe and prosperous life. As an effect, the reproduction has successfully increased the literacy and recognition of both the government and public that they have the right to live in Merapi. 
By raising cultural literacy, the public is introduced to the validity and greatness of volcanic ritual practices as a strength for communities to attain safety and well-being and the right to live in disasterprone areas. In order to raise awareness and gain the public's recognition, the communities present their volcanic rituals and ceremonies as a part of Kejawen identity. The term Kejawen refers to cosmology, a world view, beliefs, and rituals, which are steeped in Islam, Hindu-Buddhism, syncretism, and local beliefs (Beatty 1999, Woodward 1998).

\section{The reproduction of volcanic rituals as a form of Kejawen identity reinforcement}

Kejawen beliefs, rituals, and culture are highly dominant in Javanese religious and cultural practices (Betty, 1999). In principle, the volcano rituals are part of the Kejawen rituals, but not widely known by the Javanese themselves. It is because the volcanic rituals are held simply and do not invite guests, so they do not become a public spectacle. Conversely, some Kejawen rituals on the south coast and in the palace with a parade always attract the public attention of hundreds or even thousands of people (Permana et al. 2017; Purnomo \& Hariyanto 2014; Triyoga 2011). Facing the lack of public attention, the Merapi people then tried to make the volcanic rituals popular to strengthen the rituals' image as part of the Kejawen. In other words, they carry out ritual politicization to strengthen their identity as part of the dominant group in society (Apeña and Acabado 2017).

The ritual politicization by strengthening up the Kejawen identity has been conducted since the 2010 Merapi eruption. This action is expected that Javanese people can appreciate and participate in sustaining the volcanic rituals as well. All hamlets then reproduced the Javanese new year ceremony or so-called Satu Suro into bigger rituals to insist that they would live safely in the new year ahead; positioning volcanic rituals as part of Kejawen identity; and developing discourse that disasters occur due to humans who have aggrieved Merapi.

Cultural literacy on the volcano belief system is increased by adding ritual processions. Prior to the 2010 eruption, the Merapi people only performed the slametan and tirakatan rituals, but after 2010, these rituals were enriched with offerings, pilgrimages, and processions around the villages. In Balerante, additional rituals were conducted in 2011 in the form of giving offerings to Eyang and the danyang. In Babatan, additional rituals were performed in 2013 in the form of giving offerings to Eyang and the spirits watching over sacred places on Merapi. In Stabelan, the rituals were developed with a pilgrimage to the grave of Sunan Bagor. Commencing in 2012, Turgo residents made processions and offering to danyang. Greater pilgrimages and offerings in the five hamlets have become a means of attaining awareness among them and visitors that they would be safe living in the KRB III. These are all open rituals, meaning that the ritual and ceremony activities can be witnessed and participated in by all residents and visitors. In fact, numerous Kejawen followers become the participants of the ritual and ceremony, seeking blessings from God and the spirit of Merapi.

Additional Satu Suro ritual processions were also performed to lend color to the Kejawen identity. It was seen in the ceremony in Turgo that includes a procession around the hamlet, which is an act of identity politics in building discourse that these rituals are no different from those performed by Javanese. Many Javanese, for example, participate in the procession around the Yogyakarta Palace fort on the night of Satu Suro. This procession is recognized as a valid part of Javanese belief and as such is considered a human right in the area of culture. It is in this light that the Merapi people practice identity politics by identifying their rituals as part of the Kejawen tradition in order to gain public recognition that their rituals are part of Javanese culture. This strategy contrasts that of the native Malay people in Bangka, who strengthen their identity to maintain their existence among settlers from other areas (Herdiyanti \& Saputra 2020).

Satu Suro ritual is also marked by the emergence of reflection on the magical power of Merapi in controlling nature in Indonesia. The Merapi people believe that Eyang of Merapi will bring disaster to those hamlets whose inhabitants destroy nature and tarnish the sanctity of the mountain. This belief 
became the dominant discourse in tirakatan ceremonies and daily life in 2011-2014. They noted that the hamlets that were badly affected by the 2010 eruption were the inhabitants who had allegedly excavated sand on a massive scale, which caused environmental damage and led to the opening of homestay businesses for sex tourism. Some studies also found the emergence of discourse that requires the sacredness of Merapi to be maintained (Purwana 2014), and revealed that disaster is a punishment for human sin (Ahimsa-Putra 2000). Some studies also affirmed that Islamic teachings claim a disaster is a curse as the result of human sin (Chester et al. 2013, Gianisa \& Le De 2018).

In 2011-2013, the Merapi people also raised discourse on disasters being caused directly as a result of the corrupt acts of leaders. By raising the idea that the cause of a disaster is linked to the destruction of political life, the Merapi people implicitly rejected the idea disseminated in religious teachings that disaster is God's way of cursing local communities (Gaillard \& Texier 2010, Chester et al. 2013). This discourse demonstrates how the Merapi people reproduced the Javanese view on the Merapi eruptions as a mystical political process (Schlehe 2006), and as a sign that a political crisis will occur leading to a change of power (Dove 2008). Since 2014, discourse emerging from the Satu Suro night procession has changed this political crisis theme to a theme of social justice. They believe that Merapi will remain stable as Jokowi is considered to be a populist leader who is just. Therefore, the reproduction of the Satu Suro ritual in the form of the development of pro-people's political discourse strengthens the political tradition of the Javanese, who view the Merapi eruptions as punishments from God for the country's leaders, and not its people.

\section{The reproduction of volcanic rituals as a form of show-off of safety and well-being}

The relocation program implicitly and explicitly gives the stigma that people who live in Merapi have a fatalistic attitude because they were desperate to live in disaster-prone areas (BNPB \& BAPPENAS 2011). Conversely, the five hamlet communities have in fact proven that they are capable to live in a safe, secure, and prosperous way. Therefore, to fight the stigma that has already spread, they have made hamlet cleansing ceremonies as an event used to show off evidence that they can live more prosperous after the 2010 disaster. The hamlet's cleaning celebration is also a celebration of their political victory in resistance to the government's relocation program.

Organizing art performance and celebrations are an important part of commemorating political victories (Antlöv 2002). The cleansing ceremonies have been reproduced for political victories that appear at the procession of cleansing of natural water springs, shadow puppet performance, pilgrimage, cultural ceremonies, banquets, speeches from officials, art performances, and distribution of blessed food (gunungan) to residents. These additional rituals are aimed at attracting many spectators from outside the area and even the sub-districts to attend to celebrate.

A pilgrimage to the ancestors' grave is commonly conducted by all households in Balerante, Turgo, Babatan, and Stabelan. This ritual procession symbolizes both the struggle of ancestors in building the hamlets and the gratitude for the blessings from God and Eyang of Merapi that protect and provide prosperity. Meanwhile, the shadow puppet performance and local art events lead to a large community gathering with a huge audience from outside of the sub-districts. By far, the village residents have been able to meet the food needs and eat well. They even have a traditional market gathering sellers from both inside and outside the village. According to informants, all ritual processions implicitly emphasize that there is no reason for the government to force a relocation for them to a new place.

Kaliuranglor was the liveliest hamlet in celebrating the hamlet cleansing ritual on a massive scale. For the last six years (2014-2019), this cleansing celebration had lasted for four days by conducting a kenduri, a pilgrimage and cleansing the natural springs, a shadow puppet, and finally art ceremonies, including a banquet and distribution of gunungan. The gunungan event was always the highlight and attracted the attention of both locals and those from outside. 
As a political action, the hamlet cleansing ceremony succeeds in generating the accommodative attitude from the government and public that the hamlets are able to live a safe, peaceful, and prosperous life even though they live in disaster-prone areas. The hamlet cleansing ceremony in Kaliuranglor, for example, has successfully become a major event in Srumbung Sub-district. This event has turned into a community gathering that attracts the attention of hundreds of outside supporters. This cleansing ceremony also received public appreciation due to the local popular mass media and social media (Rachma 2018, Kedaulatan Rakyat Jogja 2016). In the cleansing ceremony, 2019, the Magelang government even claimed this event as a district cultural event in the mountainous region.

\section{Conclusion}

This article had described and explained the reproduction of volcanic rituals as political action in the five hamlets after the 2010 Merapi eruption. Before the 2010 eruption, these hamlets held volcanic rituals as a part of their adaptation to the threat of catastrophic eruptions. These volcanic rituals were conducted utilizing mitigation, reconstruction, and appreciation, and gratefulness for life on the slopes of Merapi. Nevertheless, the Merapi people then developed a reproduction of volcanic rituals as a form of political action, as a protest to the government programs on disaster reduction which undermined their cultural adaptation and right to live in Merapi.

This article showed that the reproduction of volcanic rituals by far gave positive effects. This reproduction is significant as an effort to obtain recognition from the government and society regarding the rights of the Merapi people to stay in their homes even in disaster-prone areas. The success in gaining recognition was obtained because in reproducing the volcanic rituals they preserve Kejawen as Javanese cultural identity and traditions. Therefore, the reproduction of volcanic rituals becomes the cultural strength of local communities against the hegemony and domination of the presence of the state that threatens their freedom and rights to live in disaster-prone areas. Finally, lessons learned from the reproduction of volcanic rituals reveal that ritual politicization at the local level is a citizen's control of the state.

\section{References}

Ahimsa-Putra HS (2000) Peringatan, cobaan dan takdir: Politik tafsir bencana Merapi. Masyarakat Indonesia 26 (1):27-54.

Aisyah N \& Purnamawati I (2012) Tinjauan dampak banjir lahar Kali Putih, Kabupaten Magelang pasca erupsi Merapi 2010. Jurnal Teknologi Technoscientia 5 (1):19-21.

Antlöv H (2002) Negara dalam Desa, Patronase Kepemimpinan Lokal. Yogyakarta: Lappera Pustaka Utama.

Beatty A (1999) Varieties of Javanese Religion: An Anthropological Account. Cambridge: Cambridge University Press.

BNPB \& BAPPENAS (2011) Rencana Aksi, Rehabilitasi, dan Rekonstruksi Wilayah Pascabencana Erupsi Gunung Merapi di Provinsi DIY dan Provinsi Jateng Tahun 2011-2013. Jakarta: BNPB.

Boogert JVD (2017) The role of Slametan in the discourse on Javanese Islam. Indonesia and Malay World 45 (133):352-372. https://doi.org/10.1080/13639811.2017.1345166.

Brewer J (2000) Ethnography: Understanding Social Research. London: McGraw-Hill Education.

Bronto SD \& Hartono G (1996) Variasi luncuran awan panas Gunung Merapi dan bahayanya. In: Proceedings of the 25th Annual Convention of the Indonesian Association of Geologist, STTN \& Akademi IP Yogyakarta, 1996, Jakarta.

Chester DK, Dukan AM, \& Dhanhani HAG (2013) Volcanic eruptions, earthquakes, and Islam. Disaster Prevention and Management 22 (3):278-292.

Donovan K \& Suharyanto A (2011) The creatures will protect us. Geoscientist 21 (2):12-17.

Dove MR (2008) Perception of volcanic eruption as agent of change on Merapi Volcano, Central Java. Journal of Volcanology and Geothermal Research 172 (3-4):329-337. https://doi.org/10.1016/j. jvolgeores.2007.12.037. 
Dove MR \& Hudayana B (2008) The view from the volcano: An appreciation of the work of Piers Blaikie. GeoForum 39 (2):736-764.

Gaillard JC \& Texier P (2010) Religions, natural hazards, and disasters: An introduction. Religion 40 (2):81-84. https://doi.org/10.1016/j.religion.2009.12.001.

Geertz C (1981) Abangan, Santri, Priyayi dalam Masyarakat Jawa. Jakarta: Balai Pustaka.

Gianisa A \& Le De L (2018) The role of religious beliefs and practices in disaster: The case study of 2009 earthquake in Padang city, Indonesia. Disaster Prevention and Management 27 (1):74-86.

Gunawan (2015) The wisdom of the community on the southern slopes of Merapi, Sleman District-The Special Region of Yogyakarta. Sosio Informa 1 (2):189-212.

Heilbronner O (2015) "Resistance through rituals"-Urban subcultures of Israeli youth from the late 1950s to the 1980s. Israel Studies 16 (3):28. https://doi.org/10.2979/israelstudies.16.3.28.

Herdiyanti PRW \& Saputra PP (2020) Identitas orang Jerieng dalam negosiasi budaya. Masyarakat, Kebudayaan dan Politik 33 (2):184-191. http://dx.doi.org/10.20473/mkp.V33I22020.184-191.

Heywood A (2013) Politik (4 ${ }^{\text {th }}$ edition in Indonesian). Yogyakarta: Pustaka Pelajar.

Holmgaard SB (2019) The role of religion in local perceptions of disasters: The case of post-tsunami religious and social change in Samoa. Environmental Hazards 18 (4):311-325. https://doi.org/10 .1080/17477891.2018.1546664.

Hudayana B (2017) Kuasa Harmoni: Adapatasi orang Merapi terhadap Erupsi. In: B. Hudayana (ed.) Pemberdayaan Masyarakat: Bunga Rampai Antropologi Terapan. Yogyakarta: Pustaka Pelajar. 206-230.

Kedaulatan Rakyat Jogja (2016) Merti Bumi di kaki Merapi, mohon terhindar bencana lahar. Kedaulatan Rakyat Jogja. [Accessed 25 October 2018]. https://www.krjogja.com/berita-lokal/jateng/kedu/ merti-bumi-di-kaki-merapi-mohon-terhindar-bencana-lahar/.

Kuswijayanti ER \& Dharmawan AD (2007) Krisis-krisis socio-politico-ecology di kawasan konservasi: Studi kasus ekologi politik di Taman Nasional Gunung Merapi. Sodality 1 (1):41-66. https://doi. org/10.22500/sodality.v1i1.5938.

Kyoo-Man H (2015) The role of religious beliefs and institutions in disaster management: A case study. Religions 6 (4):1314-1329. https://doi.org/10.3390/rel6041314.

Lapeña QG \& Acabado SB (2017) Resistance through rituals: The role of Philippine "native pig" (Sus scrofa) in Ifugao feasting and socio-political organization. Journal of Archaeological Science Reports 13:583-594. https://doi.org/10.1016/j.jasrep.2017.05.009.

Lukes S (1975) Political ritual and social integration. Sociology 9 (2):289-308. https://doi.org/10.1177 $\% 2 \mathrm{~F} 003803857500900205$.

Marshall DA (2002) Behavior, belonging, and belief: A theory of ritual practice. Sociological Theory 20 (3):360-380. https://doi.org/10.1111/1467-9558.00168.

Nazaruddin M (2013) Natural hazard and semiotic changes on the slope of Mt. Merapi, Indonesia. Master Thesis, Department of Semiotics, Faculty of Philosophy, University of Tartu, Estonia.

Pardo N, Wilson H, Procter JN, Lattughi E, \& Black T (2015) Bridging Māori indigenous knowledge and western geosciences to reduce social vulnerability in active volcanic regions. Journal of Applied Volcanology 4 (5):1-20.

Permana SA, Setyowati DL, Slamet A, \& Juhadi (2017) Community rituals in facing volcanic eruption threat in Java. Komunitas 9 (1):29-36. https://doi.org/10.15294/komunitas.v9i1.7069.

Purnomo HN \& Hariyanto W (2014) Pemaknaan mitigasi kutural dan struktural masyarakat lereng selatan Gunungapi Merapi. Jurnal Tata Kota dan Daerah 6 (1):5-20.

Purwana BHS (2014) Merapi yang suci dan pariwisata yang kotor: Benturan nilai-nilai religi dan ekonomi yang memperlemah potensi ritual sebagai mitigasi bencana di Desa Umbulharjo, Sleman. Patrawidya 15 (1):55-72.

Rachma F (2018) Tradisi Merti Bumi Merapi warga Kaliuranglor Magelang. Berita Magelang. [Accessed 25 October 2018]. http://beritamagelang.id/tradisi-merti-bumi-merapi-warga-kaliuranglor-magelang.

Reinhart K (2015) Ritual feasting and empowerment at Yanshi Shangcheng. Journal of Anthropological Archaeology 39:76-109. https://doi.org/10.1016/j.jaa.2015.01.001.

Schlehe J (1996) Reinterpretation of mystical traditions: Explanations of a volcanic eruption in Java. Anthropos 91:391-409.

Sherry J \& Curtis A (2017) At the intersection of disaster risk and religion: Interpretations and responses to the threat of Tsho Rolpa Glacial Lake. Environmental Hazards 16 (4):314-329. 
Triyoga LS (2011) Merapi dan Orang Jawa: Persepsi dan Kepercayaannya. Yogyakarta: Grasindo.

Wessing R (2006) A community of spirits: People, ancestors, and nature spirits in Java. An Interdisciplinary Journal of Southeast Asian Studies 18 (1):101-111.

Woodward MR (1998) The Slametan: Textual knowledge and ritual performance in Central Javanese Islam. History of Religions 28 (1):54-89. 